\title{
Yeni Kamu Yönetimi Anlayışı Çerçevesinde Türk Gümrük İdarelerinde Değişim: Yetkilendirilmiş Gümrük Müşavirliği Sistemi Değerlendirmesi
}

\author{
The Change In The Turkish Customs According To The New Public Management: An Evaluation Of \\ The Authorized Custom Brokers System
}

\author{
Didem ÖZÇELİK \\ YL Öğrencisi, Kocaeli Üniversitesi, \\ Yönetim Bilimleri A.B.D., \\ ozcelikdidem@hotmail.com \\ https://orcid.org/0000-0001-7975-7636
}

\author{
Makale Başvuru Tarihi / Received: 19.12.2018 \\ Makale Kabul Tarihi / Accepted: 25.03.2019 \\ Makale Türü / Article Type: Araştırma Makalesi
}

Anahtar
Kelimeler:
Kamu Yönetimi,
Yeni Kamu
Yönetimi Anlayışı,
Yetkilendirilmiş
Gümrük
Müşavirliği,

Anahtar

Keywords:

Public

Administration,

The New Public

Management,

Authorized Custom Brokers,

\section{ÖZET}

Devlet çok fonksiyonlu bir mekanizmadır ve toplumdaki nüfus artışı devletin bu fonksiyonlarını yerine getirmesini zorlaştırmaktadır. Devletin sunduğu hizmetlerin çoğalması dolayısılyla devletin büyümesi, süreçleri uzatmış, verimi düşürmüş ve devlete hantal bir yapı kazandırmıştır. Yeni Kamu Yönetimi Anlayışı devletin görevlerinin aksamasının önüne geçmeyi ve süreçleri hızlandırmayı, etkin, kaliteli ve verimli hizmet sağlanmasını amaçlamaktadır. 2008 yılında çıkartılan 60 Seri No.lu Gümrük Genel Tebliği ile Türk Gümrük Iddarelerinde köklü bir değişikliğe gidilerek Yetkilendirilmiş Gümrük Müşavirliği Sistemi (YGMS) yürürlüğe girmiştir. Eskiden gümrük memurları tarafindan yapılan birtakım işlemler, bundan böyle "yetkilendirilmiş" gümrük müşavirleri (YGM) tarafindan yerine getirilmeye başlanmıştır. Bu işlemler arasında en çok tartışma konusu olan gümrüklü antrepolarda yapılan ve henüz vergisi ödenmemiş ithalat eşyalarının girişlerinin ve çıkışlarının denetiminin YGM'ler tarafindan gerçekleştirilmesidir ancak çalışmada diğer YGM tespitlerine de yer verilmiştir. Çalışmanın amacı Yeni Kamu Yönetimi Anlayışı çerçevesinde YGM Sistemi'ni örnek vererek açılklamaktır. YGM Sistemi gümrük işlemlerinde süreçleri kısaltan, gümrüklerdeki iş yükünü azaltan, kayıt dışılığın ve özellikle antrepolardaki olası kaçakçılığın önüne geçmeyi sağlayabilecek yeni bir iş sahasıdır. Çalışma sırasında Yeni Kamu Yönetimi Anlayıșı ile ilgili kitaplardan, makalelerden ve 4458 Sayılı Gümrük Kanunu ve Kanuna bağlı yönetmeliklerden, tebliğlerden yararlanılmıştır. Gümrük mevzuatı çok geniştir ve detaylı kurallara sahiptir. YGM Sistemi gümrük mevzuatının küçük bir kısmı olsa da çalışmanın bu ilgi çekici mevzuatla alakalı yapılacak diğer araştırmalara da katkı să̆layacağı düşünülmektedir. 


\section{GIRİS}

Devlet tarafından sağlanan hizmetlerin sayısındaki artış, devletin büyümesiyle olumsuz olarak sonuçlanmıştır. Toplumdaki nüfus artışının da etkisiyle işlem süreçleri uzamaya başlamıştır. Her ne kadar teknolojinin gelişmesi büyük katkılar sağlasa da geleneksel kamu yönetimi anlayışı toplumun değişen ve artan ihtiyaçlarını karşılamakta yetersiz hale gelmiştir.

Bürokrasi kavramı çoğu zaman olumsuz anlamda kullanılmaktadır. Bürokrasinin çeşitli anlamları, devletin gelişme ve büyüme süreci ile yakından ilişkilidir (Eryılmaz, 2008:3). Bürokrasi bir örgütü tanımlayan bir kavram olmaktan çıkıp uzun ve sancılı süreçleri ifade etme şeklinde dönüşmüştür. Bunda hizmetin toplumdaki bireylere ulaşırken geçen sürenin etkisi vardır.

Geleneksel kamu yönetimi anlayışı "bürokrasi”" engellerine takılmış, kuralları esnemeye müsait olmayan, merkeziyetçi bir yapıya sahiptir. Yeni kamu yönetimi anlayışı ise devleti bu karmaşık ve bürokratik yapısından kurtarabilmek için bir çözüm arayışıdır, etkin, verimli, hesap verilebilir, geriye dönük ve şeffaf bir yönetimi işaret etmektedir.

Devlet mekanizmasına olan bakışta yaşanan bu değişim ülkemizde Gümrük sektörüne de yansımıştır. Gümrük Müsteşarlığı tarafından 19.01.2008 tarihinde yayımlanmış olan 60 Seri No.lu Gümrük Genel Tebliği (Gümrük İşlemleri) bu değişimin sonuçlarından biri olarak görülebilir. İlgili tebliğde eskiden gümrük memurlarının yaptığ 1 birtakım işlemlerin bundan sonra özel şirketler aracılığı ile gümrük müşavirleri tarafindan gerçekleştirmesi hükmü bulunmaktadır.

Klasik anlamdaki gümrük müşavirliğinden ayrilan bu özel şirketlerde "yetkilendirilmiş" olarak addedilen gümrük müşavirleri memurların yaptığı denetimleri ve raporlamaları gerçekleştireceklerdir. Yetkilendirilmiş gümrük müşavirleri faal olarak 2009'dan beri gümrüklerde kendilerine tebliğler ve genelgeler yoluyla verilen görevleri, yine belirlenen sınırlar içerisinde gerçekleştirmektedirler.

Çalışmada yeni kamu yönetimi anlayışı çerçevesinde YGM Sistemiyle ilgili bilgi verilecektir. Devletin fonksiyonlarını yürütebilmesi, hizmetin daha kaliteli ve etkin hale gelmesi için üzerindeki yükleri hafifletmesi, gerektiği takdirde bu fonksiyonlarını kısmen YGM Sistemi’nde olduğu gibi özel şirketlere devrederek, yalnızca kural koyucu ve denetleyici bir rol yüklenmesi gerekmektedir.

\section{KAMU YÖNETIMINDE DEĞİŞIM}

Çalışmanın önemi açısından kamu yönetimi kavramına kısaca değinilmesi gerekir. Özer’e göre (2005:27-28) kamu yönetiminin 3 genel anlamı vardır. Birinci anlam devlette veya bağlı kuruluşlarda hizmet verenlerin davranışlarıyla alakalıdır, ikinci olarak devletin amaçlarını gerçekleştirecek insan gücü ve yönetimi ve üçüncü olarak da kamusal örgütler bütünü olarak özetlenebilir.

Kamu yönetimi, devlet mekanizmasının var olma sebebi olan kamu yararının sağlanması amacıyla ve kamu hukuku çerçevesinde hizmet veren, kamuya ait politikalar tayin ederek uygulanmasını sağlayan merkezi yönetimler ve yerel yönetimler, ilişkiler, toplum ile bunların tamamının yönetilmesidir. Yeni yaklaşımlara göre geleneksel kamu yönetimi, özellikle Weber'in savunduğu katı hiyerarşiye sahip olan bürokratik örgütlenme modeli var olan sorunların çözümünde yetersiz kalmıştır (Özer, 2005:203-204). Devlet mekanizmasına ve devletin fonksiyonlarına karşı beklentiler değişmiştir, devlet mekanizması gelişen topluma ve bu toplumun ihtiyaçlarına yetişememektedir. Geleneksel kamu yönetiminin yerini daha esnek ve daha modern bir yönetim şekline bırakması gerektiği düşünülmeye başlanmıştır.

\subsection{Geleneksel Kamu Yönetimi Anlayışının Sorunları}

Geleneksel yönetim anlayışı Weber'in öngördüğü bürokrasi yönetimiyle uyumlu olarak örgütlenmiştir. Bu modelde yönetimde tarafsızlığı, verimli ve etkin hizmet sağlamayı hedefleyen kurallar aslında şekilcidir ve katı bir hiyerarşiye, merkeziyetçiliğe dayanır (Bilgiç, 2008:31).

Günümüzde bürokrasi kelimesi sıkl1kla devlet dairelerinde geçen uzun süreçleri veya birden fazla devlet dairesinde birden fazla kamu görevlisi aracılığıyla yapılmak zorunda olan işlemlerin süreçlerini ifade etmek için kullanılmaktadır. 
Weber'in bürokratik örgütlenmesi verimsizlik, hantallık ve kırtasiyecilikle eş anlamlı bir hale gelmiştir. Bu şekilci ve kuralcı bürokrasi anlayışı kaynak israfına sebep olmaktadır ve muhafazakardır, dolayısıyla yeniliğe kapalıdır. Bu anlayışa göre en iyi bürokrat, verilen emirlere sorgusuz sualsiz uyan, suya sabuna dokunmayan, mevcut yapıyı muhafaza eden bürokrattır (Bilgiç, 2008:37).

Geleneksel kamu yönetimi yaklaşımının birden ortadan kalkması ve hemen yerine yeni bir yaklaşımın benimsenmesi beklenemez ancak bunun olması gerektiği ortadadır. Geleneksel kamu yönetiminde, yönetim süreci değişen toplumun ihtiyacına cevap veremeyen, kamu sektöründe etkinliğin sağlanması açısından pek başarılı olamamış, modası geçmiş ilkeler olarak görülmektedir. Özellikle Weberci bürokrasi modeline yani geleneksel kamu yönetimi yaklaşımdan temellerinden birine karşı ciddi eleştiriler yapılmıştır (Ömürgönlüşen, 2003:13).

Bu eleştiriler yalnızca yönetimle ilgili sorunlara yönelik değildir, devletin örgüt kısmını yani devlet görevlilerini de ilgilendirmektedir. Devletin fonksiyonlarını daha aktif hale getirmek, verilen hizmetin kalitesini ve etkinliğini arttırmak ancak bunun için bürokratların da bu değişime dahil olması gereklidir.

\subsubsection{Refah Devletinin Krizi}

Sanayi devrimi sırasındaki liberalizm düşüncesi, devletin kamu yararı için ekonomiye karışmasının gerektiğini savunmaktadır. 1929 yılında dünyada yaşanan ekonomik buhrandan sonra ise refah devleti anlayışı çerçevesinde kamunun yararının devlet tarafindan daha iyi gözetilebileceği söylenmiştir ancak 1970'lerde yaşanan ağır ekonomik krizlerden sonra refah devleti anlayışı da yaşanan gelişmeler karşısında yetersiz kalmıştır (Nohutçu ve Balc1, 2008:16).

Refah devleti anlayışıyla birlikte devlete düşen görevlerin çoğalması, kamunun büyümesine ve sorunların artmasına neden olmuştur (Özer, 2005:204-205). Devletin aşırı şekilde büyümesi imajının giderek olumsuz hale gelmesine neden olmuştur (Eryılmaz, 2008:2).

Devletin büyümesi neticesinde devletin fonksiyonlarında yavaşlama yaşanmıştır, mevcut katı hiyerarşi ise karar almayı ve alınan kararları uygulamayı zorlaşmıştır. Kamudaki örgütler sayıca artmıştır, bu daha fazla bürokrasi anlamına gelmektedir. Yine kamuda çalışanların sayısı artmış, dolayısıyla devlet bütçesine yeni kalemler eklenmiştir, bütçe açıkları büyümüştür. Bunların sonucu olarak vergileri arttırma yoluna gidilmiş, devlet mali açıdan da zorlanmaya başlamıştır.

Liberal düşünce esasen sınırlandırılmış devleti ve buna istinaden girişimciliğin artmasını ve seçim özgürlüğünü, özel mülkiyet ile sözleşme kurumlarına dayalı bir piyasa ekonomisini savunmaktadır. Liberal düşünceye göre devlet, kaynaklarını etkin kullanmak yerine verimsiz kullanır, fakat özel sektör piyasa ve ticaretin koşulları gereği kaynaklarını verimli ve ekonomik kullanmak zorundadır, çünkü kar etmek amacındadır. Refah devleti krizinin temelinde bu anlayışın yattığı ve kamuya ait işletmelerin özelleştirilmesi gerektiği düşüncesi öne çıkmıştır. Refah politikalarının bırakılması, devletin ekonomiye artık karışmaması, kamu kurumlarının mümkün olduğu kadar küçülmesi gerektiği ve dolayısıyla piyasanın kendi kurallarına göre düzenlenmesi gerektiği düşünceleri ön plana çıkmıştır (Eryılmaz, 2008:235).

\subsubsection{Devletin Büyümesi}

Devletin ve bürokrasinin ortaya çıkmasında nüfusun artması, ticaretin ortaya çıkması, örnek olarak yerleşik hayata geçişle birlikte toprağ işlemek üzere inşa edilen sulama sistemleri ve tabi ki savaş gibi faktörlerin büyük etkisi olmuştur. Örneğin Çinliler diş tehlikelerden kendilerini korumak amaciyla Çin Setti gibi önemli bayındırlık işlerine girişmek zorunda kalmışlardır (Eryılmaz, 2008:73-74). Geçmiş zamanlarda nüfusun bu kadar fazla olmadığı, devletten beklenen hizmetlerin bu kadar komplike olmadığı düşünüldügünde devleti yönetmenin, kural koymanın ve topluma hizmeti ulaştırmanın nispeten daha kolay olduğu anlaşılabilir.

Günümüzde ise devletler tarafından verilen hizmetler sayı olarak artmış ve nitelik olarak da değişmiştir. Bunların sonucunda devletler yapı olarak büyümüştür ve komplike bir hal almıştır. Ayrıca kamu kurumlarında hizmet verenlerin sayısı ile kamuya ayrılan bütçeler arttırılmıştır (Eryılmaz, 2010:2).

Bugün devamlı olarak büyümekte olan devlete ve kamu yönetimine karşı bütün dünyada birçok eleştiri getirilmektedir. Devletin sınırlandırılması ve küçültülmesi, yönetişim, yerelleşme ve özelleştirme açısından yapılan bu eleştiriler, teoriden uygulamaya geçirilerek kamu yönetiminin yeniden şekillendirilmesi gerektiğini göstermektedir. Başta ABD'de ve Japonya'da olmak üzere, birtakım Avrupa ülkelerinde yönetim anlayışında değişim sürecine girilmiştir, 1970'li yıllardan beri yeni kamu yönetimi yaklaşımı çerçevesindeki birçok düşünce liberal politikalara neden olmuştur. Artık devletin büyümesini ve merkezileşmeyi durdurmak öncelikli olmuştur. 
Devletin büyümesini durduracak ve hatta tersine küçülmesini sağlayacak, sivil topluma gücünü ve hareketliliğini geri verecek önlemlerin alınması şarttır. Devlet örgütünün daha etkin ve verimli hale getirilmesi ile devletin sosyal hayatın birçok bölümünden çekilerek diğer alanlarda ise radikal değişiklikler sağlayacak politikaları benimsemesi, günümüzde ciddi bir gereklilik haline gelmiştir. Artık devletin görevi, kuralları koyarak bu kurallara uyulmasını sağlamak olmalıdır, yani devlet artık bir hakem görevini üstlenmelidir. Zira büyüyen ve hizmet süreçleri ağırlaşan devletin olumsuz etkilerinden korkan toplum, birtakım hizmetlerin özel sektöre devredilmesine razı olmaktadır. Dolayısıyla kamu yönetimindeki bu değişim toplumun kendisinden de destek almaktadır (Özer, 2005:13-15).

Benzer hususları Türkiye'de de görmemiz mümkündür. Günümüzde bazı özel üniversitelerin sayısı ve giriş puanları devlet üniversiteleriyle yarışır haldedir. Örneğin özel hastaneler toplumumuz tarafindan devlet hastanelerine tercih edilebilmektedir. Devlet kuralları koyduğu sürece ve mevzubahis özel kuruluşların devletin koyduğu kurallara uygun hareket edip etmediğini kontrol ettiği sürece, artık ağır gelen ve yerine getirmekte zorlandığı birtakım fonksiyonları özel sektöre devredebilir, neticesinde ise hantal yapısından kurtularak denetleyici bir rol üstlenebilir.

Devlet örgütünün büyümesinin nedenleri arasında; sanayileşmeyi, ticaret ve sanayi faaliyetlerinin maliyetlerini, devletin ekonomiyle ilgili olarak müdahale etme ve kontrol etme isteğini, siyasi olarak da ekonomi de dahil birçok alanda aktif rol almayı istemesini, nüfus artışlarını, kentleşmeyi, kamu hizmetlerinin sayısındaki artışını ve bütün bunların neticesinde kamu yönetiminde verimsizlik, etkin olamama gibi pek çok olumsuz unsuru saymak mümkündür. Devletin büyümesinin sonucunda kamu yönetimi de büyümüştür. Kırtasiyecilik artmıştır ve halkın devlete olan güveni azalmıştır ayrıca toplumdaki bireylerin yönetime katılmaları da mümkün olmayan bir hal almıştır. Esasen enflasyonun artmasının, bütçe açıklarının ve kamuya ilişkin harcamalarındaki artışların kaynağı devletin büyümesidir. Bu durum toplumları huzursuz etmiştir, devletin faaliyetlerinin azaltılmasına ilişkin görüssler ile devletin yetkilerinin bireylerden topluma aktarılmasıyla ilgili görüşler öne çıkmışır (Özer, 2005:128-129).

Devlet örgütüyle birlikte kamu kurumlarının da büyümesi yönetimi halktan ve halkı yönetimden uzaklaştırmıştır. Artan nüfusun ve değişen, sayıca çoğalan toplum beklentilerinin karşılanamaması halkın yönetimlere karşı olan bakışında olumsuz yönde değişikliklere sebep olmuştur. Özel sektöre ait kuruluşların varlığı ve özel sektörün işletmecilik yöntemlerini kamu sektöründe uygulamak, hem kamunun üzerindeki yükleri azaltacaktır hem de kamu kurumlarının toplumun ihtiyaç duyduğu kaliteli, verimli ve etkin hizmeti ulaştırmasını sağlayacaktır.

Bilgiç'e göre devlete yüklenen roller şu konularla sınırlı olmalıdır;

- Devlet mal ve hizmet üretimi için bu hizmetleri sağlayan kurumlara gereken sistemi hazırlamalıdır ve piyasadaki rekabeti sağlamalıdır.

- Bürokrasi toplumlar tarafından denetim altında tutulmalıdır ve devlet buna imkan sağlanmalıdır.

- Performans ölçümünde girdilerden çok çıtılara dikkat edilmelidir.

- Vatandaşlar özel sektördeki gibi müşsteri olarak düşünülmeli ve vatandaşa seçenekler sunulmalıdır.

- Sorunlar mümkün mertebe önceden görülebilmelidir, ayrıca mümkün ise ortaya çıkmadan müdahale edilebilmelidir.

- Tüketim ve harcama yapmanın yanında kamuda kazanma unsuru ön planda olmalıdır.

- Katılımcı yönetime ve yerel yönetime yönelim sağlanmalıdır.

- Kamu belirli hizmetlerin sağlanmasında tekel olmamalıdır, aksine özel ve gönüllü kuruluşlar arasında bir katalizör rolü oynamalıdır (Bilgiç, 2008:37).

Özetle daha önce de bahsedildiği gibi devlet örgütü kanunları koyarak, bunlara uyulmasını sağlamalı ve artık birçok alanda geri planda durmalıdır. Böylece devlet örgütsel olarak küçülecektir, özel sektörü denetimi altında tutabilecektir ve bu şekilde topluma daha fazla yarar sağlayabileceği bir konuma gelecektir. 


\subsection{Yeni Kamu Yönetimi Anlayışı}

1970'li yılların sonlarına doğru yönetimle ilgili yaklaşımlarda ciddi değişimler yaşanmıştır. Hizmette etkinliğin ve verimliliğin sağlanması, yönetime katılım ve yönetimde açıklık, yönetişim kavramı, geleneksel yönetime istinaden ortaya atılan işletmeci yönetim fikri ve hatta bağımsız olan idari otoriteler gibi kavramlar ortaya çıkmıştır (Bilgiç, 2008:30).

Yeni yöntemler ve çözüm arayışları devletin büyümesinin kaçınılmaz bir sonucudur. Nüfusun artışı ve küreselleşme ile birlikte toplumun devlete olan bakışı ve devletten beklentisi değişmiştir. Bu beklentileri karşılamakta çıkmaza düşen devlet mekanizmasının geleneksel yöntemleri terk etmesi gereklidir. Bu değişim tek seferde veyahut kısa bir sürede gerçekleşecek değildir ancak elzemdir.

Devletin birtakım faaliyetleri yerine getirebilecek nitelikli piyasalar ve özel kuruluşlar oluşturulmasına yasal zemin hazırlayarak, bu faaliyetlerin özel sektördeki firmalarca gerçekleştirilmesi ve devletin kurallarını koyduğu bu özel sektörü denetim altında tutarak hizmetlerin yerine getirilmesinin sağlaması fikri de önem kazanmıştır.

\subsubsection{Ortaya Çıkışı}

1970’lerde devlet örgütünün ekonomik büyümeyi ve özgürlüğ̈ sınırlandıran sorunlara yol açtığı konuşulmaya başlanmıştır. Buna göre örgüt olarak küçük bir devlet mekanizmasının etkinliği arttırarak toplam refahın iyileştirilmesini sağlayacağı ve devletin faaliyet alanlarının hukuki olarak sınırlandırması gerektiği görüşleri önem kazanmıştır. $\mathrm{Bu}$ düşüncelerin ortaya çıkmasında kamu fonksiyonlarındaki maliyet artışları, klasik görevlerin yerine getirilmesinde ve hangi görevlerin öncelikli olarak yerine getirileceğinde sorunlar çıkması, vergilerdeki aşırı artış, kamu örgütlerinin artık yönetilememesi ve hizmetlerde açıklığın, şeffaflığın sağlanamaması gibi sebepler sayılabilir. Dolayısıyla geleneksel kamu yönetimi anlayışının tıkanması ve yetersiz kalması sonucunda yeni bir yönetim anlayışı arayışına gidilmiştir, bu yeni anlayışın kamu sektörü için en önemli amac1; hizmette etkinliği ve verimliliği arttırmak olarak açıklanabilir (Özer, 2005:205-206).

Güdülen amaç devleti geleneksel fonksiyonlarını yerine getiren bir mekanizma haline getirmek ve bu fonksiyonların daha etkin ve verimli olmasını hedefleyerek kamu yönetiminde ekonomik ve siyasal rasyonelliği geliştirmektir. Yeni kamu yönetimi anlayışının ortaya çıkmasını sağlayan sebeplerden en önemlileri kamu yönetiminin yetersizlikleri ve 1980'li y1llardan sonra kamu yönetimine yöneltilen eleştiriler, ekonomi teorilerinde yaşanan değişimler, özel sektörün hızla ilerlemesi ile küreselleşmenin etkileridir (Eryılmaz, 2008:234).

Devletin fonksiyonlarının artması sonucunda topluma sunulması öngörülen hizmetlerin kalitesinin azalması, bu hizmetlerin ulaşmasının yavaşlaması neticesinde yeni bir yönetim anlayışı arayışına girilmesi son derece anlaşılabilir bir durumdur. Geleneksel kamu yönetimi artık ağır eleştirilere maruz kalmaktadır ve bunun sebebi artık ihtiyaçlara cevap veremiyor oluşudur.

Artık geleneksel bir örgütlenme şeklinden özel sektördeki örgütlenmeye daha yakın yani daha esnek ve katılımcı, çalışanları yetkilendirmeye açık, verimli ve etkin hizmeti amaçlayan, müşteri yani vatandaş odaklı, yeni bir kamu yönetimi anlayışına doğru gidilmektedir. Yeni Kamu Yönetimi olarak bahsedilen bu anlayışın asıl amacı devletin etkin ve verimli hizmeti ulaştırmasını sağlamaktır (Nohutçu, 2006:278).

Katılımcı bir yönetim, eski yönetim anlayışının toplumun devlet örgütlerine karşı olan bakış açısında açmış olduğu yaraların ve toplumla kamu yönetimi arasındaki mesafenin kapanmasına yardımcı olacaktır. Etkin ve verimli hizmet olguları toplumun ihtiyaçlarını doğru karşılamaya yönelik olgulardır, böylece sınırlı kaynakların etkin kullanımı sağlanabilecektir, halk bütçe açıkları neticesinde ağır şekilde yüklendiği vergilendirmelerden nispeten azad edilmiş olacaktır.

Yeni Kamu Yönetimi ile ilgili reform süreci, refah devleti uygulamalarına bir tepki niteliğindedir. Ortaya çıkan sorunlar refah devleti politikaları ve bu politikaların devam edip etmemesi gerektiği hususunu tartışmaya açmışır. Piyasa eleştirileri artık devlet mekanizmasına yöneltilmeye başlanmıştır. Etkinliği sorgulanan artık piyasa değildir, devlettir. Daha önce piyasaya olan güvensizlikten dolayı kamulaştırılan birçok hizmet, devlete olan güvenin azalmasından ötürü piyasaya bırakılmaya başlanmıştır. Bu yıllarda özelleştirme, kamudaki krizi aşmak üzere bir yöntem olarak kullanılmıştır. Artık kamu yönetimi, siyasal alanda faaliyet gösterse de içinde bulunduğu krizi aşmak için piyasa değerlerini göz önünde bulundurarak piyasa araçlarını kullanmaya başlamalıdır (Al, 2008:12-14). 
Devletin fonksiyonlarını yerine getirmekte zorlandığı, sayıca artan kamu kuruluşlarının ve kamu personeli giderlerinin yük haline geldiği ve vergilerin arttırılması yoluna gidildiği bir süreçte, ayrıca değişen hizmet anlayışı karşısında devletin çaresiz kalması sonucunda, bütün bunların toplumu doğal olarak rahatsız ettiği ortadadır. Neticede nispeten daha küçük çapta bir devlet organizasyonuna dönüş formülü de değerlendirilmeye başlanmıştır. Ayrıca toplum yönetimin karar sürecinde yer almak istemektedir, şeffaf ve hesap verebilen bir sistem toplumun tercih edeceği bir sistemdir.

\subsection{2. Özellikleri}

Yeni kamu yönetimi anlayışı kaliteli hizmeti ve kaynakların etkin kullanımını öngören bir yönetim yaklaşımıdır. Geleneksel kamu yönetiminin hantal yapısına, kırtasiyeci kimliğine, katı hiyerarşisine çözüm olarak yerine şeffaf yönetim anlayışını, performans yönetimini, etkin ve verimli hizmet anlayışını önermektedir. Neticede kamu yönetimi kısıtlı kaynaklara sahiptir, bu kaynakları savurgan bir şekilde kullanmak hizmetin kalitesinde düşüşe ve vergilerin arttırılmasına, borçlanmaya yönelime sebep olacaktır, bu hususlar kamusal alanı ve kamudan hizmet alan toplumu rahatsiz edecektir.

Yeni kamu yönetimi anlayışına göre geleneksel kamu yönetimindeki yalnızca siyasi liderliğe karşı var olan sorumluluk anlayışı haricinde halka karşı sorumluluk ilkesinin de dikkate alınması gerekmektedir. Yeni kamu yönetimi anlayışında bürokratlar sadece kurallara uymakla görevlerini ifa etmiş sayılmamaktadır, sonuçtan da sorumludurlar (Bilgiç, 2008:37).

Kamu örgütleri artık etkinliğe ve üretkenliğe önem vermektedirler, maliyetlere ve rasyonelliğe dikkat etmektedirler. Kamu yönetimleri hizmet verdikleri topluma dönük bir anlayışı benimsemeye başlamışlardır. Sundukları hizmetlerle, yaptıkları harcamalarla ve kullandıkları kaynaklarla ilgili topluma daha fazla bilgi vermektedirler. Kamu çalışanlarının geleneksel olarak sahip oldukları yetkilerde değişiklikler yapılmıştır, hesap verilebilirliğe önem verilmeye başlanmıştır. Amaç daha esnek ve yenilikçi dolayısıyla yeniliklere daha kolay ayak uydurabilecek bir dinamizm yakalamaktır (Nohutçu, 2006:277-278).

Yeni kamu yönetimi anlayışında önemle altı çizilen kavram etkinlik, özel sektörde ve de kamu sektöründe asıl amaç olan mevcut olan kaynakları, imkanları ve süreyi mümkün olan en ekonomik ve maksimum yararı sağlayacak şekilde kullanmak olarak tanımlanabilir. Bugün dünyada kamu yönetiminde etkinliği sağlamanın oldukça karmaşık bir sorun olarak görülmesi normaldir çünkü kamusal alanda hizmet sektöründe girdilerin ve çıktıların belirlenmesi kolay olmamaktadır. Kamu hizmetlerinde çıktıların maddi değerinin belirlenmesi oldukça güçtür ve kamuda hizmetin ucuz ancak kaliteli olması düşüncesi, maddi konulardan önce gelmektedir. Kamunun verdiği hizmetlerde verimliliğin ve karın ölçülmesinin zor olması, etkinliğin ölçülmesini de etkilemektedir (Özer, 2005:114-115). Halbuki özel sektörde kaynakların kullanımı ile girdiler ve çıktılar hususlarında daha dikkatli davranılmaktadır. Neticede ticaret kar etme amacıyla yapılır, özel şirketlerde kar etmek ve piyasadaki rekabet koşulları gereği daha kaliteli hizmeti daha ucuza sunabilmek esastır. Yeni kamu yönetimi anlayışı özel sektördeki bu hususların kamu kuruluşlarında da uygulanabileceğini savunur.

Yeni kamu yönetimi anlayışı esnek karar alma süreçlerine sahip yapılara önem vermektedir, karar alma sürecinin hızlandırıldığı ve yetkinin paylaşılabildiği ayrıca hizmeti alan topluma yüzü dönük bir yönetim şeklini savunur. Artık şeffaf yönetim şekilleri ve hesap verilebilir bir sistem düşüncesi tartışılmaktadır.

Yeni kamu yönetimi anlayışının savunduğu bir diğer kavram olan verimlilik, girdi olarak kullanılan kaynaklar ile çıktılar arasındaki ilişki şeklinde açıklanabilir. Mümkün olduğunca aza indirgenen girdilerden, daha fazla çıktı oluşmasını sağlamayı amaçlamaktır. Ancak kamu kuruluşları özel sektör kuruluşları kadar verimli çalışamamaktadır. Çünkü özel sektörün yeni teknolojilerden sürekli olarak yararlanmasına karşılık, kamu yönetiminde böylesine güçlü bir teknolojik alt yapı ve kaynak bulunmamaktadır. Eldeki teknolojilerden de gerektiği gibi yararlanılamamakta ve özel sektörde verimli çalışmanın ödüllendirilip başarısızlıkların cezalandırılmasına karşılık, kamu kuruluşlarında böyle bir ödüllendirme ya da cezalandırma uygulaması yapılmamaktadır (Özer, 2005:118-119). Günümüzde birçok kamu kuruluşunda performans yönetimi değerlendirmeleri yapılmaktadır. Kamu görevlilerinin liyakat esasına dayalı olarak göreve getirilmesi, uygulamalara ve kamu görevlisi kavramına da nitelik kazandıracaktır. Yeni kamu yönetimi anlayışının savunduğu bütün bu özelliklerin mümkün mertebe kamu kuruluşlarında da uygulanmaya başlaması gerekmektedir. 


\subsubsection{Geleneksel Kamu Yönetimi ile Yeni Kamu Yönetimi Anlayışı Arasındaki Farklılıklar}

Geleneksel kamu yönetimi anlayışında kurallara bağlılık esastır, merkeziyetçi ve katı bir hiyerarşi sistemi vardır. Yetkinin üst ve tek bir mevkide toplanması, kuralların uygulamasını zorlaştırmaktadır. Geleneksel düşüncede ön planda olan hizmeti alacak olan toplumun memnuniyeti değildir, daha çok kuralların yerinde uygulanıp uygulanmaması önemlidir ayrıca maliyetler hususunda mümkün olduğunca katı bir tavır sergilenmektedir. Genelde kamu görevlileri kanunlara uygun işlem yapmaya çalışırken, kanaat kullanmakta ve esnek davranmakta tereddütlü hareket etme eğilimindedirler. Dolayısıyla hizmetin kalitesinde bir artış değil, tersine bir düşüş olduğunu söylemek, işlem süreçlerinin uzamasını esnek olmayan uygulama yöntemlerine bağlamak mümkündür. Geleneksel kamu yönetimi hizmeti alacak olan toplumun yönetime katkı sağladığı yani yönetişimin sağlandığı bir yapıya sahip değildir. Yeni Kamu Yönetimi bu durumu değiştirmeyi, yetki paylaşımını arttırmayı, işlerin nitelikli kişilerce yapılmasını yani liyakati sağlamayı, nispeten daha esnek ve tölere edilebilecek uygulamaları hedeflemektedir. Örneğin özel şirketlerdeki gibi performansa dayalı bir ücret sistemi kamu görevlilerin motivasyonu arttıracaktır. Hiyerarşinin yumuşaması, görevlilerin sorumluluk alma isteğini ve kurumlarına, mesleklerine duydukları güveni arttıracaktır. Hizmeti alan topluma yüzü dönük bir devlet kurumu, ihtiyaçlara daha etkin bir şekilde karşıllk verecektir ve en önemlisi toplumun kurumlara olan güvenini arttıracaktır, toplum yönetimde daha çok söz sahibi olmuş olacaktır.

Eryılmaz'a göre geleneksel kamu yönetimi ile yeni kamu yönetimi anlayışı dört temel konuda farklı yaklaşım içindedirler (Eryılmaz, 2008:236-239);

- Birinci olarak bu yeni kamu yönetimi anlayışı, Max Weber'in bürokrasisine dayalı olan örgütlenmenin karşısında durmaktadır. Bu kuralcı bürokrasi, yönetenlerin risk almasını engellemekte, araçlarla amaçların yer değiştirmesine sebep olmakta, kıt olan kamu kaynaklarının etkin ve verimli bir biçimde kullanılması yerine, israfına yol açmaktadır. Yeni kamu yönetimi anlayışı ise kamu örgütünün yapı olarak esnek, daha yumuşak bir hiyerarşiye sahip, geniş yatay çevreli, dar merkezli ve adem-i merkeziyetçi olması gerektiğini savunur.

- İkinci olarak geleneksel kamu yönetiminde devlet mekanizması hizmetlerin üretilmesinde ve halka ulaştırılmasında direkt olarak rol sahibi olmak ister. Yeni kamu yönetimi yaklaşımına göre devletin faaliyet alanının küçültülmesi, piyasa mekanizmasından daha fazla yararlanılması ve devletin hakemlik rolünün ön plana çıkması gerekir. Yeni yönetim anlayışı, kamu hizmetleri konusunda devlete garantörlük ve hakemlik rolünü, toplumsal sorunlar konusunda ise devlete kamu, özel sektör ve gönüllü kuruluşlar arasında katalizör görevini biçmektedir. Devletin denetleyici yönüne önem vermektedir.

- Üçüncü olarak yeni kamu yönetimi anlayışı, kamu bürokrasisinin sadece siyasi liderliğe karşı değil, hizmetin sunulduğu topluma, vatandaşa karşı da sorumlu olması gerektiğinin altını çizer. Kamu kurumlarının etkinlik ve verimlilik hedefleri ile siyasetçilerin topluma verdikleri sözleri arasında denge sağlanması amacındadır.

- Son olarak yeni kamu yönetimi anlayışı, özel sektörle daha çok işbirliği yapılması gerektiğini, özel sektör kuruluşlarında uygulanan yönetim tekniklerinin kamu kuruluşlarında da uygulanabileceğini savunmaktadır. Geleneksel kamu yönetimi anlayışında, özel işletmelerin yönetimi ile kamu yönetimi arasında kesin çizgiler vardır. Yeni kamu yönetimi yaklaşımı, özel sektör ile kamu yönetimi arasında var olan farklılıkların giderek azalması gerektiğine dikkat çekerek, kamu yönetiminin sunduğu hizmetlerde de verimliliğin ve kalitenin sağlanması, vizyonların ve misyonların belirlenmesi, ekip ruhu, girişimcilik ve işletmecilik ruhuna sahip yöneticiler, müşteri (toplum), piyasa ve pazar gibi kavramlara önem verilmesi gerektiğini savunmaktadır. 
Tablo 1. Geleneksel Kamu Yönetimi ve Yeni Kamu Yönetimi Anlayışı Arasındaki Farklar

\begin{tabular}{|c|c|}
\hline Geleneksel Yönetim & Yeni Yönetim \\
\hline Sorumluluk/risk almaya isteksiz & Sorumluluk/risk almaya istekli \\
\hline Yetkiyi toplayan & Yetkiyi paylaşan \\
\hline Gizlilik & Açıklık \\
\hline Kuralcı ve kırtasiyeci & Vizyon sahibi ve esnek \\
\hline Katı hiyerarşi & Yumuşak hiyerarşi \\
\hline Otoriter & Profesyonelce \\
\hline Kişiye bağlı statü & İş ve performansa bağlı statü \\
\hline Sabit ücret & Performansa bağlı ücret \\
\hline Kapalı enformasyon kanalları & Açık enformasyon kanalları \\
\hline Çatışmacı ilişkiler & Karşı1ıklı işbirliği \\
\hline Birey yönetimli & Ekip yönetimli \\
\hline Örgüt merkezli & Müşteri/vatandaş merkezli \\
\hline Yakından kontrol & Performans hedefli \\
\hline Karar akışı yukarıdan aşağıya & Karar akışı her iki yönde \\
\hline Değerlendirme yukarıdan aşağıya & Değerlendirme her iki yönde \\
\hline Sınırlı iş gören katkısı & Azami iş gören katkısı \\
\hline Bürokrat tipi yönetici & Girişimci yönetici \\
\hline Mal ve hizmetlerde nicelik & Mal ve hizmetlerde kalite \\
\hline Kitlesel Üretim & Farkl1lığı esas olan üretim \\
\hline
\end{tabular}

Kaynak: Eryılmaz, 2008:240.

Devletin yapısı küçülmekte ve faaliyet alanları daraltılmakta; piyasaya, sivil topluma ve bireye doğru bir yetki kayması yaşanmaktadır. Artık hiç kimse devletin büyütülmesini önermemektedir. Piyasa temelli yönetim anlayışında devletin yeni rolü, hakemlik ve hizmetler konusunda garantörlük biçimine dönüşmek durumundadır (Ery1lmaz, 2008:260-261).

Devlet mekanizmasının küçülmesi neticesinde devlet kural koyucu ve düzenleyici haline gelecektir. Devletin denetim görevi devam edecektir ve hatta Eryılmaz’a göre sorumluluğu artacaktır. 


\section{TÜRK GÜMRÜK İDARELERİNDE DEĞISŞIM}

Kamu yönetiminde yaşanan sıkıntılara, kamunun bir parçası olan gümrüklerde de rastlanabilir. YGM Sistemi'nden önce gümrüklerdeki personel yetersizliği ve buna rağmen artan diş ticaret hacmi ile yükümlü sayısı işlerin sekteye uğramasına sebep olmaktaydı. Gümrük memurlarının iş yoğunluklarına bağlı olarak antrepolarla birebir ilgilenilememesi neticesinde yapılması gereken denetim mevzuatın ön gördügü şekilde gerçekleştirilememekteydi.

Bu durumu düzeltme amacıyla, zamanın Gümrük Müsteşarlığı 19.01.2008 tarihli 26761 no.lu Resmi Gazete'de yayımlanan 60 Seri No.lu Gümrük Genel Tebliği ile Yetkilendirilmiş Gümrük Müşavirliği Sistemi'nin (YGM Sistemi) temellerini atmıştır. Tebliğin amacı, "Ekonomik etkili gümrük rejimleri, nihai kullanım, basitleştirilmiş usul uygulamaları ve diğer gümrük işlemlerinin doğru olarak uygulanmasını sağlamak için yapılması gerekli tespit işlemlerinin belirlenmesi ile bu işlemlerin yerine getirilmesine ilişkin usul ve esasları belirtmek" şeklinde belirtilmiş olup ilgili tespit işlemleri ve bu işlemlerin nasıl yerine getirileceği aynı Tebliğin ve sair mevzuatın koyduğu kurallar çerçevesinde olmak üzere açıklanmıştır (60 Seri No.lu Gümrük Genel Tebliği, 1. madde).

Tebliğe göre özellikle antrepolarda yapılması gereken birtakım işlemler, eşya girişlerinin ve çıkışlarının kaydedilmesi ve bu eşyaların denetlenmesi ile antrepolarla ilgili ön inceleme raporları ve diğer bazı gümrük işlemleriyle; süre uzatımı raporları, menşei tespitleri ve daha birçok tespit raporu, yine Tebliğdeki hükümlere istinaden yetkilendirilen gümrük müşavirleri tarafindan gerçekleştirilecektir.

Gümrük sektöründe yeni bir iş alanı, istihdam yaratılmıştır. Gümrük müşaviri belgesi sahibi kişiler yetkilendirilmiş gümrük müşaviri (YGM) olmak için Bakanlığa başvurarak "Yetki Belgesi" aldıktan sonra Tebliğde geçen denetimleri ve tespitleri yapabileceklerdir.

Amaç bir anlamda gümrük memurlarının yerine denetim yapmak ve denetimle alakalı Tebliğde belirlenen aralıklarla ve Tebliğde belirtilen şekil ve usullere dayanarak raporlama yoluyla hem ilgili gümrük idarelerine hem de Bakanlığa bilgi vermektir. Böylece gümrük memurları kendi mesai saatleri içerisinde, asli görevleri olan devletin diğer işleriyle ilgilenebileceklerdir. Aynı zamanda YGM şirketleri hem yerel gümrük idareleri hem de Bakanlık tarafından denetim ve kontrol altında tutulmaya devam edilmektedir.

\subsection{Mevzuat Değişikliği}

01.09.2009 tarihi antrepolarda YGM Sistemi için bir milat sayılabilir. İlk aşamada gümrüklü antrepoların gümrük memurlarından YGM'lere devri gerçekleştirilmiştir. Neticede YGM Sistemi devreye girdiğinde gümrüklü sahalara sahip antrepolarda eşya girişleri ve çıkışları devam etmekteydi ve halihazırda antrepolarda mevcut eşyalar bulunmaktaydı. Bu eşyaların tam tespiti yapılarak devir-teslim tutanakları imzalanmıştır ve YGM'ler görevlerine başlamışlardır.

Antrepo, müşavir, gümrüklü saha, gümrüklü eşya gibi terimlere haiz olabilmek için YGM mevzuatını ve ilgili tanımları gözden geçirmek gereklidir. Bundan sonraki bölümde 6 Seri No.lu Gümrük Genel Tebliği’nden ve tanımlardan bahsedilecektir.

\subsection{Gümrük Genel Tebliği (Yetkilendirilmiş Gümrük Müşavirliği)(Seri No: 6)}

2008'den günümüze YGM'lerle ilgili mevzuat sıklıkla değişse de YGM Sistemi'nin dayanağı öncelikle 4458 Sayılı Gümrük Kanunu ve bu Kanuna bağlı Gümrük Yönetmeliği ile 6 Seri No.lu Gümrük Genel Tebliği'dir. Kanun Müsteşarlık'a gümrük mevzuatının doğru uygulanabilmesi için gerekli gördüğü bütün önlemleri alma yetkisi vermiştir, dolayısıyla Müsteşarlık gerekli görülen birtakım gümrük işlemlerinin belirlenecek şartlara sahip gümrük müşavirleri tarafından yürütülmesi hususlarında yetkili kılınmıştır (Gümrük Kanunu, 10. madde). Gümrük müşavirleri Kanun tarafindan her türlü gümrük işlemini yerine getirmekle görevlendirilmiş kişilerdir (Gümrük Kanunu, 226. madde). Yetkilendirilmiş Gümrük Müşavirleri ise klasik gümrük müşavirliğinden farklı olarak Müsteşarlıkça belirlenen birtakım tespit işlemlerini yerine getiren belli birtakım şartları taşıyan ve yetki verilmiş olan gümrük müşavirleri şeklinde tanımlanarak ayrı bir niteliğe sahiptir (Gümrük Yönetmeliği, 574. madde).

İlgili kanun ve yönetmelik maddelerinden yola çıkarak, Müsteşarlığın gümrük mevzuatının doğru uygulanabilmesi adına YGM Sistemi'ni oluşturduğu anlaşılabilir (4458 sayılı Gümrük Kanunu, 10/1-(c) bendi). 
Bir gümrük müşavirinin "yetkilendirilmiş" statüsünü kazanabilmesi için öncelikle doğrudan veyahut dolaylı temsil suretiyle iş yapmayı bırakması ve yetki belge numarası alarak yetkilendirilmiş gümrük müşaviri olması gerekmektedir yani bir müşavir aynı anda hem gümrük müşaviri hem de yetkilendirilmiş gümrük müşaviri olamaz.

Güncel ve geçerli olan 6 Seri No.lu Gümrük Genel Tebliği’nin amacı Yetkilendirilmiş Gümrük Müşavirliği Sistemi'nin (YGMS) daha etkin ve verimli bir şekilde işlemesini sağlamak olup aslen YGM Sistemi'ni düzenlemeye yöneliktir (6 Seri No.lu Gümrük Genel Tebliği, 1. madde).

6 Seri No.lu Gümrük Genel Tebliği'nin 1. maddesinde geçen bazı tanımlara aşağıda yer verilmiştir, çalışmanın anlaşılması açısından incelemekte yarar vardır:

- Genel Müdürlük: Gümrükler Genel Müdürlüğünü,

- Gümrük Müşaviri: Eşyanın gümrükçe onaylanmış bir işlem veya kullanıma tabi tutulmasına ilişkin gümrük işlemlerini dolaylı temsil yoluyla takip eden, sonuçlandıran ve kendilerine Bakanlıkça gümrük müşavirliği izin belgesi verilen kişiyi,

- Tespit İşlemi: Tebliğ kapsamında YGM tarafından yapılacak tespit işlemlerini,

- Tespit Raporu: YGM tarafından tespit işlemleri için gerekli inceleme ve araştırmanın tamamlanmasını müteakiben şekil ve içeriği rehberde yer alan rehberin ilgili bölümlerinde belirtilen usul ve esaslara uygun şekilde düzenlenecek raporu,

- Tespit Sözleşmesi: YGM ile yükümlü arasında özel hukuk hükümlerine istinaden yapılan sözleşmeyi,

- Yetki Belgesi: Adına düzenlendiği gümrük müşavirinin Tebliğ kapsamında tespit ve raporlama işlemlerini yapmaya yetkili olduğunu gösteren belgeyi,

- Yetki Numarası:YGM'lerin tespit ve raporlama işlemlerini yaparken kullandığı ve ilgili sözleşmelerde ve raporlarda geçen numarayı,

- Yetkilendirilmiş Gümrük Müşaviri: Tebliğ kapsamındaki tespit işlemlerini yapan ve sonucunda tespit raporu düzenleyen, Bakanlıkça adına yetki belgesi düzenlenen gerçek kişi veya tüzel kişi ortağı gümrük müşavirini,

- Yükümlü: Tebliğ kapsamındaki tespit işlemlerini yaptırmak üzere YGM'ler ile sözleşme imzalayan kişiyi ifade eder (6 Seri No.lu Gümrük Genel Tebliği, 4. madde).

- Gümrük Gözetimi: Gümrük mevzuatına ve gereken hallerde gümrük gözetimi altındaki eşyaya uygulanacak diğer hükümlere uyulmasını sağlamak üzere gümrük idareleri tarafından genel olarak uygulanan işlemlerdir (4458 sayılı Gümrük Kanunu, 3. madde, 12. fikra)

- Gümrük Denetimi: Gümrük mevzuatına ve gereken hallerde gümrük gözetimi altındaki eşyaya uygulanacak diğer hükümlere uyulmasını sağlamak üzere eşyanın muayenesini, belgelerin varlığının ve gerçekliğinin kanıtlanmasını, işletme hesaplarının, defterlerinin ve diğer yazılı belgelerin tetkikini, nakil araçlarının kontrolünü, bagajların ve kişilerin yanlarında ya da üstlerinde taşıdıkları eşyanın kontrolünü, idari araştırmalar ve benzeri diğer işlemlerin yapılması gibi özel işlemlerin yerine getirilmesidir (4458 sayılı Gümrük Kanunu, 3. madde, 13 fikra).

- Elleçleme: Gümrük gözetimi altındaki eşyanın asli niteliklerini değiştirmeden istiflenmesi, yerinin değiştirilmesi, büyük kaplardan küçük kaplara aktarılması, kapların yenilenmesi veya tamiri, havalandırılması, kalburlanması, karıştırılması ve benzeri işlemlerdir (4458 sayılı Gümrük Kanunu, 3. madde, 22. fikra).

- Antrepo: Gümrük antreposu, gümrük gözetimi altında bulunan eşyanın veya izin verildiği durumlarda serbest dolaşımda bulunan eşyanın ihraç edilmek kaydıyla konulduğu genel ve özel antrepoları ifade eder (Gümrük Yönetmeliği, 328. madde). Gümrüklü antrepolar, genel antrepo veya özel antrepo olabilir. Genel antrepolar, eşyanın konulması için herkes tarafından kullanılabilen, özel antrepolar ise yalnız antrepo işleticisine ait eşyanın konulması amacıyla kurulan gümrük antrepolarıdır (4458 sayılı Gümrük Kanunu, 94. madde).

Antrepolarla ilgili tartışmaların daha iyi anlaşılması adına antrepo; ithalat vergisi ödenmemiş ancak Türkiye Gümrük Bölgesi'ne girişi gerçekleștirilmiş eşyaların konulduğu ve muhafaza edildiği gümrüklü depolar olarak tanımlanabilir. Bu eşyalar serbest dolaşımda değildir, "serbest dolaşımda" tanımı eşyayla alakalı gümrük 
işlemlerinin yerine getirilmesi yani eşyanın ilgili vergilerinin ödenmiş olması anlamına gelir. Dolayısıyla gümrüklü sahaların bulunduğu antrepolarda bulunan ilgili eşyaların denetiminin ve güvenliğinin sağlanmasının, kaçakçılığın ve vergi kaybının önlenebilmesi adına çok önemli olduğu söylenebilir. Antrepo işletmeciliği ciddi sorumluluk gerektiren bir meslektir, cezai sorumluluğu da hayli fazladır.

\subsubsection{YGM Olmak İçin Gerekli Şartlar}

YGM olabilmek için gerekli şartları açıklarken, gümrük müşavirliğine de değinmek gerekir. Gümrük müşaviri, Bakanlıkça kendisine gümrük müşavirliği karnesi olarak da bilinen gümrük müşavirliği izin belgesi verilen ve yükümlü adına iş takibi yapma yetkisine haiz kişidir. Gümrük müşaviri olabilmek için; Türkiye Cumhuriyeti vatandaşı olmak, fiili ehliyet sahibi olmak, Kanunda geçen suçlardan hüküm giymemiş olmak ve yine Kanunda geçen okullardan mezun olmuş olmak gerekir. Gümrük müşaviri olmak isteyen bir kişinin, bahsedilen şartları taşıyorsa, en az 1 yıl stajyer olarak bir gümrük müşavirinin yanında çalıştıktan sonra "Gümrük Müşaviri Yardımcılığı Sınavı"ndan başarılı olması gerekmektedir. Sınavda başarılı olan adaylara Gümrük Müşaviri Yardımcılı̆̆ İzin Belgesi (B Karne) verilir.

İzin belgesini alan gümrük müşavir yardımcıs1, en az 2 y1l boyunca gümrük müşaviri yardımcıs1 olarak çalıştıktan sonra "Gümrük Müşavirliği Sınavı"na girmeye hak kazanır. Bu iki aşamalı bir sınav olup adaylar birinci aşamadaki yazılı sınavda başarılı olurlarsa, bir sonraki sözlü mülakata girmeye hak kazanırlar. Mülakatı başarıyla geçen adaylara Gümrük Müşavirliği İzin Belgesi (A Karne) verilir (4458 sayılı Gümrük Kanunu, 226. ila 228. madde).

Sınavların gümrüğe ilişkin ticari konularla ve mali konularla ilgili hazırlanmış sorulardan oluştuğunu ve oldukça geniş bir yelpazeye sahip olduğunu belirtmekte fayda vardır. Gümrük müşaviri olmak zorlu bir süreçtir, gümrük müşavirliği yoğun bir mevzuat bilgisine dayal1, her türlü yükümlülüğü ve cezai sorumluluğu büyük bir meslektir.

Tebliğde belirlenen tespit işlemlerini yapmak isteyen gümrük müşavirleri "Kanunda ve sair mevzuatta geçen birtakım konularda ceza almamış olmak, gümrük müşaviri yapmayacak olmak, mevzuatta belirtilen okullardan en az lisans seviyesinde mezun olmuş olmak ve minimum 7 yll gümrük müşavirliği izin belgesine sahip olmuş olmak, 65 yaşını doldurmamış olmak" (Gümrük Yönetmeliği, 576. madde) gibi niteliklere haiz oldukları takdirde "yetkilendirilmiş" gümrük müşaviri olarak işlem yapabilirler (6. Seri No.lu Gümrük Genel Tebliği, 5. madde). Gümrük Yönetmeliği'nin 576. maddesine aykırı durumlarda bulunan YGM'lerin yetki belgeleri geri alınır ve bununla ilgili cezai hükümler ile YGM'nin iade etmiş olduğu gümrük müşaviri izin belgesi hakkındaki cezai hükümler saklıdır (Gümrük Yönetmeliği, 578. madde).

Gümrük müşavirleri Bakanlığa başvurarak gümrük müşavirliği izin belgelerini iade ettikten sonra ve gerekli koşulları yerine getirdikleri takdirde YGM Yetki Belgesi ve Yetki Numarası alarak YGM olabilirler. YGM'lerin yetki belgelerinin süresi 3 yıldır (Gümrük Yönetmeliği, 576. madde, 2. fikra). Yetki belgesinin süre sonu gelen YGM'nin Yetki Belgesi için yeniden başvuru yapması gerekmektedir ayrıca bu 3 yıl 65 yaşını dolduracak olan müşavirler için daha kısa olarak da belirlenebilir.

\subsubsection{YGM'nin Görevleri}

YGM Sistemi'nin kuruluşunun başında bir YGM'nin görevi, 60 Seri No.lu Gümrük Genel Tebliği'nde “gümrük mevzuatının doğru bir şekilde uygulanması amacıyla gümrük işlemleriyle ilgili tespitlerin belirlenen çerçevede yerine getirmesini sağlamak" şeklinde belirtilmiş olup YGM'lerin mevzuata uygun olarak tespitlerini yapması ve tespit raporlarını bu çerçevede hazırlamaları gerekmektedir (60 Seri No.lu Gümrük Genel Tebliği, 4. Madde, 1. Fikra).

YGM'lerin birincil görevi denilebilecek ve en çok eleştiriye uğradıkları işlemler, antrepolarla ilgili yapılması öngörülen tespitlerdir. Genel ve özel antrepolarla alakalı olarak; antrepolara yapılan eşya girişlerinin ve çıkışlarının denetimleri, antrepo açılışları, antrepolarda yapılacak genişletme, daraltma ve tadilat işlemleri, adres değişiklikleri ve antrepoların devir işlemleriyle ile ilgili tespit raporlarının kodları " $A N$ " ile başlamaktadır. Antrepo işlemlerinin yanı sıra gümrük rejimleriyle ilgili ve aynı zamanda mevzuat işlemleri olarak adlandırılabilecek tespit işlemleri ise; geçici ithalat rejimine ve dahilde işleme rejimine istinaden talep edilen süre uzatımı raporları ve diğer gümrük rejimleriyle ilgili tespitler ve ibra raporları, menşe tespitleri ve örneğin ihracatı gerçekleşmiş olan eşyaların geriye dönük olarak yapılacak evrak kontrolleriyle ile ilgili sonradan kontrol raporları olarak özetlenebilir. YGM'ler bu sayılan tespit işlemleriyle birlikte diğer birçok tespit işlemlerini, yasal çerçevelerde ve mevzuata uygun olarak, belirlenmiş tekniklere dayalı araştırmalar neticesinde tamamladıktan sonra, ilgili gümrük birimlerine sunmak üzere raporlamakla yükümlüdür. 
YGM Sistemi ile ilgili yaşanan süreçte değişen yasal mevzuatta birtakım değişiklik olsa da ve birçok farklı tespit kodu YGM'lerin işlem yapması için belirlenmişse de 60 Seri No.lu Gümrük Genel Tebliği'nin genel çerçevesi değişmemiştir. Bir sonraki bölümde güncel olan YGM mevzuatı ve yapılan son değişikliklere istinaden YGM işlemleri açıklanmıştır.

\subsubsection{YGM İşlemleri}

Güncel ve geçerli mevzuata istinaden genel antrepolara ve özel antrepolara yönelik tespit işlemi raporları "AN" koduyla başlamakta olup aşağıda açıklanmıştır, ilgili kodlar YGM Yetki Numarası ile birlikte sözleşme numaralarında belirtilmektedir (6 Seri No.lu Gümrük Genel Tebliği, 11/1-(a) bendi):

1) ANl kodlu raporlar, antrepoların açılması için hazırlanan başvuru dosyalarına yapılan ön incelemeler için,

2) AN2 kodlu raporlar, antrepolarda yapılacak genişletme veya daraltma işlemleriyle ilgili başvuru dosyalarına yapılan ön incelemeler için,

3) AN3 kodlu raporlar, antrepolardaki tadilatlarla alakalı başvuru dosyalarına yapılan ön incelemeler için,

4) AN4 kodlu raporlar, antrepolarda adres değişikliği yapılmasıyla alakalı başvuru dosyalarına yapılan ön incelemeler için hazırlanan raporlardır.

5) AN5 kodlu raporlar ise antrepoların bir başka firmaya devriyle alakalı olarak hazırlanan raporlardır.

6) AN6 kodlu raporlar, özel antrepolara yapılacak eşya girişlerinin ve eşya çıkışlarının tespitini,

7) AN7 kodlu raporlar, genel antrepolarda ve özel antrepolarda var olan stok kayıtlarının altışar aylık dönemler halinde, yılda iki defa yapılması gereken tespiti,

8) AN8 kodlu raporlar, genel antrepolarda yapılacak eşya girişlerinin ve eşya çıkışlarının tespitini,

9) AN9 kodlu tespit raporu, antrepo rejimi altındaki eşyaya elleçleme yapılmasıyla ilgili tespiti kapsar.

Diğer YGM tespit işlemleri ise aşağıdaki kodlarlarla sıralanmıştır, ilgili kodlar YGM Yetki Numarası ile birlikte sözleşme numaralarında belirtilmektedir (Gümrük ve Ticaret Bakanlığı, Gümrükler Genel Müdürlüğü, 23.12.2016/21182294 tarih-no.lu 2016/21 say1l1 Genelge):

10) GCl kodlu raporlar, kısmi muafiyet veya tam muafiyet suretiyle geçici olarak ithal edilen eşyaya verilecek süre uzatımı raporlarını,

11) GC2 kodlu raporlar, ithalat vergilerinden muaf ve geçici olarak ithal edilen özel nitelikli belli eşyaların kullanılması sonucunda ortaya çıkan ürünlerin tamamının ya da önceden belirlenmiş olan miktarlarının ihraç edildiğine dair tespiti,

12) DRl kodlu raporlar, dahilde işleme izni verilen eşyaya verilecek süre uzatımı raporlarını ifade eder.

13) $O K 1$ kodlu raporlar, Onaylanmış Kişi Statüsü Belgesi başvurularına ilişkin dosyaların ön incelemesinin yapilmasidir.

14) SK1 kodlu raporlar, ihracatın yapılmasının ardından geriye dönük olarak sonradan kontrol yapılması talep edilen EUR.MED, EUR.1 ve A.TR Dolaşım Belgelerinin, Fatura Beyanlarının ve EUR.MED Fatura Beyanlarının doğruluklarının ve mevzuata uygun olduğunun tespitini,

15) GKl kodlu raporlar, gümrük kontrolü altında işleme rejimi çerçevesine yapılacak ibra işleminin raporların1,

16) INF4 kodlu raporlar, tedarikçi beyanı çerçevesinde INF4 Bilgi Formu düzenlenecek ihracata konu eşyanın menşeinin tespitini,

17) NK1 kodlu raporlar, nihai kullanım konusu eşyanın amacına uygun kullanıldığının veya kullanılmadığının tespitini ifade eder.

18) ATl kodlu raporlar, ithal edilip kullanıldıktan sonra ihracatının yapılması istenen ve A.TR Dolaşım Belgesi düzenlenmek istenen eşyayla alakalı birtakım belgelerin mevzuatta geçen saklanma sürelerinin geçmesi sebebiyle, eşyanın serbest dolaşımda olduğunu gösteren diğer birtakım belgeler esas alınarak yapilacak olan tespiti,

19) AT2 kodlu raporlar, A.TR Dolaşım Belgelerinin dönemsel olarak kontrol edilerek mevzuata uygun olduğunun tespitini, 
20) EU1 kodlu raporlar, EUR.MED ve EUR.1 Dolaşım Belgelerinin, EUR.MED Fatura Beyanlarının ve Fatura Beyanlarının dönemsel olarak kontrol edilerek mevzuata uygun olduğunun tespitini,

21) EU2 kodlu raporlar, tercihli olarak ifade edilen ticaret anlaşmaları çerçevesinde onaylanmış ihracatçı yetkisi başvurularına konu edilen eşyanın menşe kurallarına uygun olduğunun tespitini,

22) ZD1 kodlu raporlar, yükümlülerin tecil ve taksitlendirme talebinde bulunması neticesinde yapılacak olan "çok zor durum" tespitini,

23) BD1 kodlu raporlar, gümrük beyannamelerinde yapılması talep edilen düzeltmelere ilişkin tespiti,

24) PD1 kodlu raporlar, gümrük yükümlülügünün sona ermesinin ardından belirlenmiş kurumlar tarafindan yapılmış kontrollerin sonuçlarına göre eşyanın üzerindeki gümrük gözetiminin sonlandırılmasıyla ilgili tespiti,

25) TK1 kodlu raporlar, gümrük beyannamelerinde ödeme şeklinin takas olarak beyan edilmesi sonucunda KKDF muafiyetinin uygulanmasiyla ilgili tespiti ifade eder (http://www.mavi.web.tr/ygms/).

YGM'ler tespit kodlarıyla ilgili işlem yapmadan önce yükümlü olan taraf ile ilgili tespit kodu üzerinden sözleşme yaparlar ve bu sözleşmeye istinaden ilgili tespit koduna göre YGM tespit raporu tanzim ederler. Her raporun yine mevzuatta belirtilmiş iş günü süreleri içerisinde ilgili gümrük birimlerine sunulması gerekmektedir.

YGM'lerin yaptığı tespit raporları aslında birçok tespit kodu açıklamasından da görüleceği üzere "ön inceleme" raporudur. YGM'ler tespitlerini gümrüğe sunduktan sonra ilgili gümrük birimleri kendi incelemesini yapmaya devam etmektedir. Dolayısıyla YGM raporunun sonucu ilgili gümrük müdürlüğü tarafından değerlendirilerek, evrakların toparlanması, incelenmesi ve olumlu ya da olumsuz bir sonuca varılması hususlarında gümrük müdürlüklerindeki işlem yükünü büyük oranda azaltmakta olduğu düşünülebilir.

YGM'lerin en çok eleştirildikleri tespit işlemleri "AN" kodlu işlemlerdir ve özellikle gümrüklü sahalarda yapılan, eşyanın antrepoya girişi ve antrepodan çıkışı işlemleridir. YGM'ler antrepolarda bulunan ve vergileri ödenmemiş, gümrük gözetimi ve denetimi altındaki ithalat eşyalarının antrepoya girişlerini ve çıkışlarını hem evrak üzerinden hem de fiziki olarak kontrol etmektedirler, sisteme bilgi girişlerini yaparak eşyanın antrepo içerisindeki denetimini sağlamaktadırlar. Gümrük müşavirinin tescilini yaptığı gümrük beyannamesinde beyan edilen eşyanın ticari tanımı ve kap, kilo gibi bilgileri ile yurtdışından gelen eşya için verilmiş olan beyan arasındaki uyum kontrol edilir. Sonrasında hem Bakanlık sisteminden hem YGM'lerin kendi sisteminden tespit tutanağı oluşturularak, gümrük müşavirine ve gümrük müdürlüğüne elektronik olarak gönderilir, kayıt işlemi yapılmış olur. Eşyanın çıkışı sırasında gümrük müşaviri antrepo beyannamesi ile antrepoya girişi yapılan eşyalar için, ithalat beyannamesi tescil ettirdiğinde, eşyaya tekabül eden vergi tutarının ödenmesiyle eşyanın üzerindeki gümrük gözetimi ve denetimi ortadan kaldırmış ve eşya yükümlüye ait olmuş olur ve sahibine teslim edilir. Böylece eşyanın antrepodan çıkış işlemi fiziki olarak ve fiilen gerçekleştirilmiş olur, eşyanın çıkışı bir tutanağa bağlanarak yine hem Bakanlık sisteminden hem de YGM'lerin kendi sisteminden düşümü sağlanır.

Anlatılan işlem süreci YGM'lerin günlük olarak yaptıkları işin bir parçasıdır ve her ayın sonunda aylık olarak yapılan giriş ve çıkış işlemleri rapor haline getirilerek ilgili gümrük müdürlüğüne sunulur. YGM'ler dönemsel olarak altı ayda bir yapılan eşya girişleri ve çıkışlarıyla alakalı da gümrük müdürlügüne rapor verirler, stok sayımlarını kontrol ederek olası bir hata ya da eksikliğin önüne geçilmiş olur.

YGM'ler yanlarında YGM Yardımcısı olarak tanımlanan gümrük müşaviri yardımcılarını veyahut stajyerleri çalıştırabilirler. YGM yardımcısı olmak için 4458 sayılı Gümrük Kanunu'nun 227. maddesinde belirtilen okullardan mezun olmuş olmak ve ilgili gümrük müşavirleri derneğine kayıtlı olmak gerekir, aynı şekilde YGM yardımcısının imza beyannamesi ve SGK girişi aranan evraklar arasındadır, keza bu hususlarla ilgili evrakların belirlenmiş süreler içerisinde ilgili gümrük müdürlüklerine ve yine ilgili gümrük müşavirleri derneğine sunulması gerekmektedir. Buradan YGM adına denetim ve kontrol gerçekleştirecek kişi olan YGM yardımcısının da meslek açısından yetkinlik ve nitelik sahibi personel olması gerektiği anlaşılabilir. Bir stajyerin veya gümrük müşaviri yardımcısının bağlı olduğu YGM'nin yanında çalıştığı süreler, gümrük müşaviri yardımcılığı sınavı ve gümrük müşavirliği sınavları için gerekli çalışma/staj süresi yerine sayılabilmektedir.

YGM yardımcısı antrepoya giren ve çıkan eşyayı YGM'nin adına denetlemekle yükümlüdür. Şu an yürürlükte olan 6 Seri No.lu Gümrük Genel Tebliği'ne istinaden; bir YGM iki adet A tipi genel antrepoyu geçmemek üzere toplamda dört adet antreponun tespit işlemlerini gerçekleştirebilir. Dolayısıyla YGM'ler yardımcı veyahut stajyer ile işlemlerini yürütmeyi tercih etmektedirler. 
YGM Sistemi'nden önceki uygulamada bir gümrük memuru aynı anda birkaç antreponun denetimini sağlamaya çalışmaktaydı. YGM Sistemi ile birlikte başlayan bu süreçte, bundan böyle bir gümrük memuru devletin kendisine verdiği esas görevleriyle ilgilenebilmektedir. Dolayısıyla YGM'lerin antrepo işlemleriyle birebir sorumlu olduğu bir sistemin, gümrük memurlarının üzerinden bu yükü aldığını söylemek yanlış olmaz.

\subsubsection{YGM ile GM Arasındaki Farklar}

6 Seri No.lu Gümrük Genel Tebliği'nde gümrük müşavirinin ve yetkilendirilmiş gümrük müşavirinin tanımları şu şekilde yapılmıştır:

- Gümrük Müşaviri: Eşyanın gümrükçe onaylanmış bir işlem veya kullanıma tabi tutulmasına ilişkin gümrük işlemlerini dolaylı temsil yoluyla takip eden, sonuçlandıran ve kendilerine Bakanlıkça gümrük müşavirliği izin belgesi verilen kişiyi,

- Yetkilendirilmiş Gümrük Müşaviri: Tebliğ kapsamındaki tespit işlemlerini yapan ve sonucunda tespit raporu düzenleyen, Bakanlıkça adına yetki belgesi düzenlenen gerçek kişi veya tüzel kişi ortağı gümrük müşavirini ifade eder (6 Seri No.lu Gümrük Genel Tebliği, 4. Madde).

YGM olabilmek için öncelikle gümrük müşaviri belgesine sahip olmak gerekmektedir. Gümrük müşaviri olabilme şartları 4458 sayılı Gümrük Kanunu'nun 228. maddesiyle düzenlenmiştir. Bir gümrük müşavirinin YGM'lik yapabilmesi için en az yedi yıl süreyle gümrük müşavirliği izin belgesine sahip olması gerekmektedir (Gümrük Yönetmeliği, 576/1-(a) maddesi). Kısaca yetkilendirilmiş gümrük müşavirleri, mevzuata istinaden yetki verilen, nitelikli gümrük müşavirleridir denilebilir. Gümrük mevzuatında gümrük müşavirleri ile yetkilendirilmiş gümrük müşavirleri arasındaki farklar kesin şekilde belirlenmiş olup gümrük müşavirleri ile yetkilendirilmiş gümrük müşavirlerinin aynı ve benzer gümrük işlemlerini takip edemeyeceklerine dair hükümler mevcuttur.

YGM'lerin Kanunda yer alan gümrük müşavirliği mesleğinin genel şartlarına ve prensiplerine aykırı hareketlerde bulunması, YGM olma şartlarından herhangi birini kaybetmeleri, YGM'nin görevini mevzuata uygun şekilde yerine getirmemiş olması ve/veya kusurlu ve hatalı yapmış olması, asgari ücretin altında hizmet verilmesi gibi durumlarda YGM'nin yetki belgesi geri alınır. Bu hususlarla alakalı olarak yetki belgeleri geri alınmış olan gümrük müşavirleri 5 yıl süre ile tekrardan YGM olamazlar, yetki belgesi alamazlar (Gümrük Yönetmeliği, 578. madde).

Yine YGM'lerin gümrük müşavirleri ya da sözleşme imzaladığı ve tespit işlemini yaptığ1 yükümlü kişiler ve/veya firmalar ile doğrudan veyahut dolaylı olarak iş ilişkisi içinde bulunması yasaklanmıştır (6 Seri No.lu Gümrük Genel Tebliği, 22/1. madde). Bütün bunlardan hareketle gümrük müşavirinin yapacağı işlemlerin ve yetkilendirilmiş gümrük müşavirinin yapacağı işlemlerin birbirinden kesin olarak ayrılmış olduğu görülebilir, gümrük müşavirleri ile yetkilendirilmiş gümrük müşavirlerinin işbirliği yapmaları ve Tebliğe göre aralarında “organik bağ” bulunması yasaktır (6. Seri No.lu Gümrük Genel Tebliği, 5. madde). Örneğin bir gümrük müşavirinin yükümlü adına beyan ettiği ihracata konu eşyanın ihracatından sonra, ihracat ülkesinden gelen talep üzerine geriye dönük olarak yapılacak sonradan kontrol işlemleri YGM tarafından yazılacak SK1 kodlu tespit raporu ile sağlanmaktadır. Bir gümrük müşavirinin beyanını verdiği ihracatın geriye dönük olarak yine bir gümrük müşaviri tarafından kontrol edilmesinin etik açıdan doğru olmayacağı aşikardır, dolayısıyla örnekteki geriye dönük yapılacak sonradan kontroller yetki verilmiş ve farklı niteliklerdeki YGM'ler tarafından gerçekleştirilmektedir.

YGM ile gümrük müşaviri arasında bir bütünlük vardır denilebilir. Vergisi ödenmemiş eşyayı antrepoya koymak için antrepo beyannamesine ihtiyaç vardır, bu gümrük müşavirinin ilgili gümrük müdürlügünde tescil ettirmesi gereken bir beyanname türüdür. Antrepo beyannamesine istinaden ilgili eşyanın antrepoya girişine ve çıkışını kayıt etmek suretiyle denetimini yapmak ise YGM'nin görevidir. Yine ihracatta büyük kolaylıklar sağlayan Onaylanmış Kişi Statü Belgesi (OKS) ön inceleme raporları YGM'ler tarafindan OK1 kodlu tespit raporu ile gerçekleştirilmektedir ancak ilgili ihracat beyannamelerini düzenlemekle gümrük müşavirleri yükümlüdür.

Geçici ithalat beyannamesi gümrük müşavirleri tarafından düzenlenmektedir ancak örneğin geçici ithalatta süre uzatımı talepleri YGM'lerin GC1 kodlu tespit raporu ile ilgili gümrügüne bildirilmektedir. Örnekler çoğaltılabileceği gibi, günümüzde YGM Sistemi’nin gümrük işlemleriyle iç içe girdiğini, gümrüklerdeki artan işlem hacmi neticesinde iş yükünü azalttıkları ancak yine ilgili gümrük birimleri tarafından sıklıkla denetlendiğini, dolayısıyla mevzuata uygun olarak gümrük işlemlerini yerine getirdiklerini anlamak zor değildir. 


\subsection{YGM Sistemiyle İlgili Görüşler}

YGM Sistemi yürürlüğe girdikten sonraki ilk yıllarda, YGM şirketleri müfettişlerce ve gümrük amirlerince yapılan birçok teftişten geçmiştir ve bu teftişler aralıklı olarak devam etmektedir. Bakanlık yetkililerin ifadelerinden birçok piyasa araştırmasının yapıldığ 1 , sistem değişikliğinden etkilenen lojistik firmalarıyla, antrepo işletmecileriyle ve gümrük müşavirleriyle görüşüldüğü anlaşılmıştır.

Yine sistemin hazırlık ve işleyiş aşamasında bizzat bulunan gümrük yetkililerinin ifadelerinden YGM Sistemi'nin gümrük sektöründeki personel sıkıntısının önüne geçebilmek için oluşturulduğu anlaşılabilir. Gümrük mevzuatı detaylı ve komplike bir mevzuattır, gümrük idareleri adına gözetim ve denetim yapan kişilerin bu kanunlara vakıf, tecrübeli olması gerekmektedir. YGM Sistemi'nin amacı gümrük mevzuatını bilen gümrük müşavirlerine bir yetki vererek, niteliklerini arttırmak ve devlet adına denetim yapmalarını sağlamaktır.

YGM'lerden önceki sistemde şu an YGM'ler tarafından gerçekleştirilen işlemlerin, gümrük müdürlüklerindeki memurlar tarafından yapılması esastı ancak gümrük memurları gümrük idarelerinde kendilerine verilen diğer görevleri de yine aynı mesai saatleri içerisinde yapmak durumunda kalıyorlardı. Birçok gümrük yetkilisine göre bu sağlıklı bir durum değildi. YGM Sistemi ile antrepolardaki denetimler sıkılaştırılmıştır, birçok gümrük işlemiyle alakalı tespit alanları oluşturulmuştur, yeni bir iş sahası belirlenmiştir. Gümrük idarelerindeki yoğunluğun bir kısmı YGM Sistemi’ne aktarılmıştır. Ayrıca YGM tespitleri neticesinde, gümrük işlemleri faturalandırmaya başlanmıştır, bu ekonomik açıdan kayıt dışılığa bir son vermek adına olumlu bir gelişmedir.

Gümrük müşaviri belgesi almak uzun ve bağl1lık gerektiren bir süreçtir. Mevzuatın sürekli güncelleniyor olması, işlemlerin devamlılığını ve ilgili mevzuata uygunluğunu sağlamak açısından iş takibini gün geçtikçe zorlaştırmaktadır. YGM mevzuatı ise, gümrük mevzuatının yalnızca bir bölümüdür ve daha özel tebliğler ile genelgeler çerçevesindedir. Dolayısıyla YGM Sistemi'nin daha spesifik olduğunu söylemek yanlış olmaz.

Birçok antrepo yetkilisi YGM Sistemi'nden ve YGM'lerin çalışma şekillerinden memnun olduklarını belirtirken, gümrük mevzuatındaki değişikliklerden şikayetçi olan antrepo yetkilileri de mevcuttur. Özelikle büyük ticari hacme sahip firmalar için önemli olan sistemin değişmesi değil, işlerliğinin sağlanmasıdır ancak sürekli değiştirilmeye çalışılan bir sistemden istikrar beklemek gülünç olur. Ticarete büyük katkılar sağlayan şirketlerin, devletin verdiği kararlarda mutabık kalmasını beklemeleri normaldir. Ancak değişim sancılı, uzun ve zor bir süreçtir. Deneme-yanılma yöntemi özellikle ticarette kabullenilebilir bir durum olmasa dahi, bu değişikliklerin sistemi iyileştirme amacı güttüğünü düşünmek gerekir.

\section{SONUÇ}

Kamu yönetimi anlayışı, devlet yönetimini daha verimli, daha etkin, daha interaktif hale getirmek adına değişim sürecine girmiştir. Yeni Kamu Yönetimi Anlayışı, geleneksel kamu yönetiminin yetersiz kaldığı ve devlet idaresinin ihtiyaç duyduğu verimli ve kaliteli hizmet anlayışını hedeflemektedir.

YGM örneğinde olduğu gibi, memurlar eskiden bir tercih yapmak zorunda kalmışlardır. Gümrük idarelerindeki olağan işlerinin yanı sıra antrepolarda görevlendirilmişlerdir. Normal olarak memurların her iki tarafa birden yetişememesi ve gümrükteki memur sayısının yetersiz olması ancak buna karşılık ticaret hacminin hızla büyümesi sonucunda özellikle antrepolarda başıboşluğa sebep olmuştur. YGM'ler bu denetimsizliğin önüne geçerek, arada bir nevi tampon görevini görmektedir. Böylece memurlara da zaman kazandırılmış, gümrük işlemleri hızlandırılmıştır.

Türkiye genelinde 1.500 'den fazla gümrüklü antrepo bulunmaktadır, bunların büyük bir kısmı İstanbul ve civarındadır. Her antrepoya bir memur atanması gümrük teşkilatının sahip olduğu memur sayısı açısından mümkün olamayacağı gibi, gümrük memurlarının mesai saatleri içerisinde sürekli antrepoda durmaları mümkün değildir. YGM Sistemi'nden önce gümrük memuru antrepo sahasında değilken antrepo işletmeleri, eşya girişlerini ve eşya çıkışlarını yapmak için memurun gelmesini beklemekle yükümlüydüler ve bu durum ticari açıdan antrepolara, dahası ithalat sürecine ve birçok gümrük işlemi sürecine zarar vermekteydi. Bu noktada devreye giren YGM Sistemi sayesinde, klasik gümrük müşavirlerinin arasından seçilip "yetkilendirilerek" göreceli olarak daha nitelikli hale getirilmiş olan, gümrük idareleri adına gümrük denetimini ve gözetimini Tebliğde belirtilen şekilde yerine getiren müşavirler yani YGM'ler ortaya çıkmıştır. YGM Sistemi gümrük sektöründe yeni bir iş sahası yaratmıştır, gümrük müşavirliği için yeni bir sayfa ve nispeten daha spesifik bir iş seçeneği olarak görülmesi de mümkündür. 
Gümrüklü antrepolar YGM'ler tarafından birebir denetlenmektedir, günümüzde birtakım gümrük işlemlerinin tespitleri de YGM'ler tarafindan yapılmaktadır. Bununla birlikte YGM'ler hem yaptıkları tespitler hususunda hem de maliye mevzuatı açısından olağan olarak denetlenmektedir. Yetkilendirilmiş gümrük müşavirliği şirketlerinin yarı özel yarı devlet statüsünde bulunduğu söylenilebilir, neticede YGM Sistemi'nin dayanağı Gümrük Kanunu ve buna bağlı gümrük yönetmeliği ile ilgili olarak yayımlanmış gümrük genel tebliğleridir.

Başlangıçtan beri birçok değişikliğe uğrayan YGM Sistemi, şu an halen yasal bir sürecin içindedir, gümrük mevzuatında birtakım değişiklikler yapılmasına devam edilmektedir. Ancak gümrük yetkililerinin, antrepo işletmecilerinin ve gümrük müşavirlerinin görüşleri ışığında, YGM Sistemi'ni tümden ya da dolaylı olarak ortadan kaldırmanın kaosa sebep olacağı söylenebilir. Gümrük idarelerinde halen yeterli sayıda ve yetişmiş personel mevcut değildir. YGM'lerin yaptığı tespitleri faturalandırarak ekonomik açıdan gümrük sektöründeki kayıt dış11ı̆̆ın önüne geçilmesine sebep olduğu da unutulmamalıdır.

\section{KAYNAKÇA}

AL, Hamza (2008), Yeni Kamu Yönetimi, Değişim Yayınları, İstanbul.

BİLGİÇ, Veysel Karani (2008), "Yeni Kamu Yönetimi Anlayışı", Kamu Yönetiminde Çağdaş Yaklaşımlar (Ed. Asım Balcı, Ahmet Nohutçu, Namık Kemal Öztürk, Bayram Coşkun), Seçkin Yayınları, Ankara, ss.31-37.

ERYILMAZ, Bilal (2008), Bürokrasi ve Siyaset, Alfa Yayınları, İstanbul, 3. Bask1.

ERYILMAZ, Bilal (2010), Kamu Yönetimi, Okutman Yayıncılık, Ankara, 3. Baskı.

NOHUTÇU, Ahmet (2006), Kamu Yönetimi, Savaş Yayınevi, Ankara.

NOHUTÇU, Ahmet ve BALCI, Asım (2008), “Kamu Yönetiminin Yeni Perspektif ve Dinamizmi: “Kamu”nun Yönetilmesinden "Kamu”"nun Yönetmesi Anlayışına Doğru”, Kamu Yönetiminde Çağdaş Yaklaşımlar: Sorunlar, Tartışmalar, Çözüm Önerileri, Modeller, Dünya ve Türkiye Yansımaları (Ed. Asım Balcı, Ahmet Nohutçu, Namık Kemal Öztürk, Bayram Coşkun), Seçkin Yayınları, Ankara, ss.13-23.

ÖMÜRGÖNLÜŞEN, Uğur (2003), “Yeni Kamu Yönetimi İşletmeciliği”, Çağdaş Kamu Yönetimi-I (Ed. Muhittin Acar, Hüseyin Özgür), Nobel Yayın Dağıtım, Ankara, ss.13-15.

ÖZER, Mehmet Akif (2005), Yeni Kamu Yönetimi, Platin Yayınları, Ankara.

4458 sayılı Gümrük Kanunu (04.11.1999 tarih ve 23866 sayılı Resmi Gazete).

Gümrük Yönetmeliği (07.10.2009 tarih ve 27369 say1lı Resmi Gazete).

60 Seri No.lu Gümrük Genel Tebliği (19.01.2008 tarih ve 26761 sayılı Resmi Gazete).

6 Seri No.lu Gümrük Genel Tebliği (07.10.2016 tarih ve 29850 sayılı Resmi Gazete).

2016/21 say1lı Genelge (Yetkilendirilmiş Gümrük Müşavirliği Uygulaması) (23.12.2016 tarih ve 82858591010.06.02-E-00021182294 sayılı Genelge, Gümrük ve Ticaret Bakanlığı, Gümrükler Genel Müdürlüğü, Gümrük Müşavirleri Dairesi).

2018 yılı Asgari Ücret Genelgesi (23.12.2017 tarih ve 30279 sayılı Resmi Gazete).

http://www.mavi.web.tr/ygms/ (Erişim Tarihi: 16.12.2018). 